\title{
PELAKSANAAN 7 KONTAK ASI PADA KEBERHASILAN MENYUSUI
}

\author{
Anggy Febriani, Kamsiah, Wisuda Andeka Marleni \\ Politeknik Kesehatan Kementerian Kesehatan Bengkulu, Jurusan Kebidanan, \\ Jalan Indragiri Nomor 03 Padang Harapan Bengkulu \\ anggyfebrianil @gmail.com
}

\begin{abstract}
The success of implementing Exclusive Breastfeeding is influenced by several factors. To achieve successful breastfeeding, the WHO has established the existence 7 ASI Contact with lactation counselor or lactation clinic. The purpose of this study was to determine the analysis of the implementation of the 7 ASI contact to successful breastfeeding in the working area of UPTD Puskesmas Pasar Ikan Bengkulu City of Year 2017. This study design using analytic survey with cross sectional approach. Total sample of 66 mothers breastfeeding $>6$ months.sampling using techniques consecutive sampling and data analysis using statistical test Chi-Square. The results showed 66 mothers breastfeeding > 6 months, most mothers have carried out 7 ASI contacts and successfully breastfeed exclusively (77.2\%). Test results Chi-Square show that there was a relationship implementation 7 ASI contacts to successful breastfeeding in the working area of UPTD Puskesmas Lingkar Barat Bengkulu City of Year $2017(\rho=0.000, \mathrm{OR}=7.088)$. The results of this study demonstrated an association implementation of the 7 ASI contact ASI to successful breastfeeding because 7 ASI contact to affecting successful of breastfeeding.
\end{abstract}

Keywords : 7 ASI Contacts, Breastfeeding Success

\begin{abstract}
Abstrak : Keberhasilan melaksanakan pemberian ASI Ekslusif dipengaruhi oleh beberapa faktor. Untuk mencapai keberhasilan menyusui, WHO telah menetapkan adanya 7 Kontak ASI dengan konselor laktasi atau klinik laktasi. Tujuan penelitian ini adalah untuk mengetahui analisis pelaksanaan 7 kontak ASI terhadap keberhasilan menyusui di wilayah kerja UPTD Puskesmas Lingkar Barat Kota Bengkulu Tahun 2017. Desain penelitian ini menggunakan survey analitik dengan pendekatan cross sectional. Jumlah sampel 66 orang ibu menyusui bayi > 6 bulan. Penentuan sampel menggunakan teknik Consecutive Sampling dan analisis data menggunakan uji statistik Chi-Square. Hasil penelitian menunjukkan dari 66 orang ibu menyusui bayi > 6 bulan, hampir sebagian besar ibu telah melaksanakan 7 kontak ASI dan berhasil menyusui secara ekslusif (77,2\%). Hasil uji Chi-Square menunjukkan bahwa ada hubungan pelaksanaan 7 kontak ASI terhadap keberhasilan menyusui di wilayah kerja UPTD Puskesmas Lingkar Barat Kota Bengkulu Tahun $2017(\rho=0,000$, OR $=7,088)$. Hasil penelitian ini menunjukkan terdapat hubungan pelaksanaan 7 kontak ASI terhadap keberhasilan menyusui sehingga pelaksanaan 7 Kontak ASI dapat mempengaruhi keberhasilan menyusui.
\end{abstract}

Kata Kunci : 7 Kontak ASI, Keberhasilan Menyusui

Menurut World Health Organization (WHO), angka kematian bayi merupakan kematian bayi yang terjadi pada kurun waktu dan tempat tertentu yang diakibatkan oleh keadaan tertentu, dapat berupa penyakit maupun sebab lainnya. WHO menyebutkan AKB sebesar 35 per 1.000 kelahiran hidup untuk tahun 2012 (Kemenkes RI, 2012).

AKB di Indonesia menurut Survei Demografi Kesehatan Indonesia angka kematian bayi sebesar 23 kematian per 1000 kelahiran hidup. Angka ini merupakan salah satu indikator derajat kesehatan bangsa. Pencapaian tersebut masih sangat jauh dari target Sustainable Development Goals $(S D G$ 's) sebesar 12 per 1.000 kelahiran hidup (SDKI, 2014).
Banyak penelitian menunjukkan betapa masa dini usia pada anak merupakan golden ages (masa keemasan) bagi perkembangan kecerdasan anak. Asupan gizi sangat penting dalam menunjang hal tersebut. Gizi yang terbaik yang baik diberikan pada anak terutama pada masa keemasannya adalah Air Susu Ibu (ASI). ASI Ekslusif memiliki manfaat yang sangat penting dan baik bagi tumbuh kembang anak. ASI Ekslusif merupakan pemberian air susu ibu sedini mungkin setelah persalinan, diberikan tanpa jadwal dan tidak diberi makanan lain, walupun air putih, sampai bayi berumur 6 bulan (Yeyeh et al, 2011).

Sebagai upaya mendukung kelancaran pemberian ASI dan mempertahankan menyusui, seorang ibu dan keluarga harus mempunyai 
motivasi dan informasi yang cukup tentang proses menyusui. Sebaiknya sejak hamil ibu dan keluarga sudah mencari informasi tentang ASI dan menyusui tersebut. Keberhasilan melaksanakan pemberian ASI Ekslusif dipengaruhi oleh beberapa faktor salah satunya faktor pengetahuan ibu tentang ASI tersebut. Pengetahuan ibu tetang pentingnya pemberian ASI harusnya dimulai sedini mungkin sejak masa kehamilan (Yahmin, 2015).

Untuk mencapai keberhasilan menyusui, WHO telah menetapkan adanya 7 kontak dengan konselor laktasi atau klinik laktasi sejak ibu hamil sampai bayi lahir dan menyusui. 7 kontak menyusui merupakan waktu-waktu khusus yang dianjurkan untuk ibu hamil sampai menyusui dan keluarga lainnya untuk bertemu dan konsultasi dengan konselor menyusui, sehingga didapatkan informasi yang benar serta relevan mengenai ASI. Dengan adanya info yang cukup mengenai ASI dan menyusui diharapkan ibu dan keluarga sudah siap dalam menjalani proses menyusui nantinya (Yahmin, 2015).

Menurut Setiawan (2015), Pelaksanaan 7 kontak ASI yang direkomendasikan WHO dimulai dari kehamilan trimester ketiga sampai pasca persalinan dan bila ditemukan masalah menyusui di luar waktu-waktu khusus tersebut. Manfaat memberikan ASI bagi ibu tidak hanya menjalin hubungan kasih sayang, tetapi dapat membantu involusi, mempercepat pemulihan kesehatan ibu, menunda kehamilan, dan mengurangi resiko terkena kanker payudara (Roesli, 2009).

Menurut Dinas Kesehatan Kesehatan Provinsi Bengkulu tahun 2016 cakupan ASI Ekslusif tahun 2016 adalah sebesar 59\%. Capaian cakupan pemberian ASI Ekslusif di Kota Bengkulu masih dibawah target nasional karena target cakupan ASI Ekslusif nasional adalah $80 \%$ bayi. Menurut Profil Kesehatan Kota Bengkulu, cakupan ASI Ekslusif terendah adalah Puskesmas Lingkar Barat(27,94\%) (Dinkes Kota Bengkulu, 2016).

Hasil penelitian Ambarwati, et al (2015), menunjukkan pengetahuan kelompok yang mendapat konseling laktasi yang intensif lebih tinggi dibanding kelompok yang tidak mendapatkan konseling laktasi. Hal ini memotivasi ibu untuk mengetahui lebih lanjut mengenai definisi dan manfaat Inisiasi Menyusui Dini (IMD), perawatan payudara, posisi menyusui dan pelekatan bayi, ketidakcukupan ASI, manfaat memerah ASI, cara memerah ASI, penyimpanan dan cara penyajian ASI perah serta bahaya susu formula sehingga keberhasilan pemberian ASI dapat tercapai.

Menurut penelitian Etika, et al (2016) kemampuan menyusui kelompok yang diberi konseling laktasi dengan penerapan media lebih tinggi dibandingkan dengan kelompok yang diberi konseling laktasi dengan asuhan standar. Hal ini sejalan dengan penelitian Ramlan, et al (2015) yang menjelaskan bahwa konseling laktasi yang intensif meningkatkan jumlah ibu yang memberikan ASI Ekslusif.

Berdasarkan survei awal di UPTD Puskesmas Lingkar Barat Kota Bengkulu selama bulan Januari sampai dengan bulan September 2017 dari 208 orang ibu menyusui, hanya sebanyak 23 orang $(33,8 \%)$ ibu menyusui secara ekslusif dan dari 3 orang ibu yang menyusui secara ekslusif 2 diantaranya melakukan 7 kontak ASI.

\section{BAHAN DAN CARA KERJA}

Desain penelitian ini menggunakan survei analitik dengan pendekatan cross sectional. Untuk mengetahui Analisis Pelaksanaan 7 Kontak ASI terhadap Keberhasilan Menyusui di Wilayah Kerja UPTD Puskesmas Lingkar Barat Kota Bengkulu Tahun 2017. Populasi penelitian ini adalah seluruh ibu menyusui bayi usia $>6$ bulan di Wilayah Kerja Puskesmas Lingkar Barat Kota Bengkulu pada 9 bulan terakhir yaitu bulan Januari - September 2017 sebanyak 208 orang. Jumlah sampel $66 \mathrm{ibu}$ menyusui bayi > 6 bulan. Penentuan sampel dilakukan menggunakan teknik Consecutive Sampling dan diperoleh sampel dari Puskesmas Lingkar Barat 66 ibu menyusui bayi $>6$ bulan.

\section{HASIL}

Analisis Pelaksanaan 7 Kontak ASI

Tabel 1. Analisis 7 Kontak ASI

\begin{tabular}{|c|c|c|c|}
\hline $\begin{array}{c}\text { Kon- } \\
\text { tak }\end{array}$ & $\begin{array}{c}\text { Konseling yang } \\
\text { dilakukan }\end{array}$ & Jumlah & $\%$ \\
\hline \multirow[t]{4}{*}{$1-2$} & $\begin{array}{l}\text { Inisiasi menyusui dini } \\
\text { (IMD)/kolostrum }\end{array}$ & 53 & 80,3 \\
\hline & Menyusui semau bayi & 63 & 95,4 \\
\hline & $\begin{array}{l}\text { Posisi dan perlekatan } \\
\text { baik }\end{array}$ & 58 & 87,9 \\
\hline & $\begin{array}{l}\text { Menyusui ekslusif 0-6 } \\
\text { bulan }\end{array}$ & 66 & 100 \\
\hline \multirow[t]{3}{*}{3} & $\begin{array}{l}\begin{array}{l}\text { Kontak antar kulit } \\
\text { (skin to skin) }\end{array} \\
\end{array}$ & 66 & 100 \\
\hline & $\begin{array}{l}\text { Bayi merangkak ke } \\
\text { payudara }\end{array}$ & 53 & 80,3 \\
\hline & Hisapan pertama & 55 & 83,3 \\
\hline \multirow[t]{2}{*}{$4-5$} & $\begin{array}{l}\text { Memberikan } \\
\text { konseling, bagaimana } \\
\text { cara menyusui yang } \\
\text { baik dan benar, } \\
\text { apakah ASI sudah } \\
\text { dihasilkan, Jelaskan } \\
\text { ASI ekslusif yang } \\
\text { optimal dan menyusui } \\
\text { semau bayi }\end{array}$ & 64 & 97 \\
\hline & $\begin{array}{lrr}\begin{array}{l}\text { Perah } \\
\text { berikan } \\
\text { cangkir }\end{array} & \text { ASI } \begin{array}{r}\text { dan } \\
\text { dengan }\end{array} \\
\end{array}$ & 52 & 78,8 \\
\hline 6 dan & Putting dan masalah & 58 & 87,9 \\
\hline
\end{tabular}




\begin{tabular}{llllll}
\hline 7 & payudara & & & \\
\cline { 2 - 5 } & $\begin{array}{l}\text { Menangis meskipun } \\
\text { disusui sering }\end{array}$ & 53 & 80,3 \\
\cline { 2 - 6 } & $\begin{array}{l}\text { Cek perlekatan dan } \\
\text { posisi }\end{array}$ & 53 & 83,3 \\
\hline Berdasarkan tabel 1 & dari & 66 & orang
\end{tabular}
reponden, kontak ke 1-2 dengan konseling mengenai memberikan ASI Ekslusif 0-6 bulan selalu diberikan kepada responden (100\%). Selain itu, kontak ke 3 yang memberikan konseling tentang kontak skin to skin juga dapat dikatakan selalu dilaksanakan (100\%). Namun pada kontak ke 4-5 dengan konseling perah ASI dan berikan dengan cangkir hanya 78,8\% dilaksanakan.

\section{Karakteristik Responden}

Tabel 2. Karakteristik Responden

\begin{tabular}{lll}
\hline \multicolumn{3}{c}{ Usia Ibu } \\
\hline 25-35 Tahun & 48 & 72,7 \\
>35 Tahun & 18 & 27,3 \\
Jumlah & 66 & 100 \\
\hline
\end{tabular}

Berdasarkan tabel 2, dari 66 orang responden ibu bayi menyusui $>6$ bulan hampir seluruh reponden berusia $25-35$ tahun $(72,7 \%)$. Sedangkan sisanya adalah ibu menyusui bayi $>6$ bulan yang berusia $>35$ tahun $(27,3 \%)$

\section{Analisis Univariat}

Analisis univariat pada penelitian ini untuk melihat distribusi frekuensi masing-masing variabel, yaitu keberhasilan menyusui ASI Ekslusif sebagai variabel dependen dan pelaksanaan 7 kontak ASI sebagai variabel independen yang dapat dilihat pada tabel berikut ini.

Tabel 3. Distribusi frekuensi Pelaksanaan 7 Kontak ASI dan Keberhasilan Menyusui

\begin{tabular}{lcc}
\hline & $\begin{array}{c}\text { Jumlah } \\
(\mathrm{n})\end{array}$ & $\begin{array}{c}\text { Persentase } \\
(\%)\end{array}$ \\
\hline Pelaksanaan 7 Kontak ASI & & \\
7 Kontak ASI & 35 & 53 \\
Tidak 7 Kontak ASI & 31 & 47 \\
Jumlah & 66 & 100 \\
\hline Keberhasilan Menyusui & & \\
Berhasil Menyusui & 37 & 56,1 \\
Tidak Berhasil Menyusui & 29 & 43,9 \\
$\quad$ Jumlah & 66 & 100 \\
\hline
\end{tabular}

Berdasarkan tabel 3, dari 66 orang ibu menyusui bayi $>6$ bulan, hampir sebagian besar ibu telah melaksanakan 7 kontak ASI yaitu sebanyak 35 orang $(53 \%)$ dan 37 orang $(56,1 \%)$ ibu yang berhasil menyusui di UPTD Puskesmas Lingkar Barat Kota Bengkulu Tahun 2017.

\section{Analisis Bivariat}

Analisis bivariat dilakukan untuk mengetahui hubungan antara variabel independen dengan variabel dependen, yaitu pelaksanaan 7 kontak ASI terhadap keberhasilan menyusui dengan menggunakan uji statistic Chi Square dengan tingkat kepercayaan $95 \%$ atau $\alpha=0,05$ yang dapat dilihat pada tabel 4.

Tabel 4. Analisis pelaksanaan 7 kontak ASI terhadap keberhasilan menyusui di wiayah kerja UPTD Puskesmas Lingkar Barat Kota Bengkulu Tahun 2017

\begin{tabular}{|c|c|c|c|c|c|c|c|c|}
\hline \multirow{3}{*}{ Variabel } & \multicolumn{4}{|c|}{ Keberhasilan Menyusui } & & & \multirow{3}{*}{ CI $95 \%$} & \multirow{3}{*}{$\rho$} \\
\hline & \multicolumn{2}{|c|}{$\begin{array}{c}\text { Berhasil } \\
\text { Menyusui }\end{array}$} & \multicolumn{2}{|c|}{$\begin{array}{c}\text { Tidak Berhasil } \\
\text { Menyusui }\end{array}$} & \multicolumn{2}{|c|}{ Total } & & \\
\hline & $\mathrm{n}$ & $\%$ & $\mathrm{~N}$ & $\%$ & $\mathrm{~N}$ & $\%$ & & \\
\hline Pelaksanaan 7 Kontak ASI & & & & & & & 7,088 & 0,000 \\
\hline 7 Kontak ASI & 27 & 77,1 & 8 & 22,9 & 35 & 100 & & \\
\hline Tidak 7 Kontak ASI & 10 & 32,3 & 21 & 67,7 & 31 & 100 & & \\
\hline Jumlah & 37 & 109,4 & 29 & 90,6 & 66 & 100 & & \\
\hline
\end{tabular}

Tabel 4. menunjukkan bahwa ibu menyusui yang melaksanakan 7 Kontak ASI sebagian besar berhasil menyusui $(77,1 \%)$ sedangkan sebagian besar ibu menyusui yang tidak melaksanakan 7 kontak ASI tidak berhasil menyusui $(67,7 \%)$. Uji hipotesis dengan menggunakan analisis Chi Square diperoleh nilai $\rho=0,000<\alpha=0,05$ yang artinya ada hubungan yang bermakna antara pelaksanaan 7 kontak ASI terhadap keberhasilan meyusui. Adapun besarnya OR yaitu 7,088 (CI 95\%) yang artinya pelaksanaan 7 Kontak ASI akan meningkatkan 7,088 kali dalam keberhasilan menyusui. Artinya terdapat hubungan pelaksanaan 7 kontak ASI terhadap keberhasilan menyusui di wilayah kerja UPTD Puskesmas Lingkar Barat Kota Bengkulu Tahun 2018.

\section{PEMBAHASAN}

Analisis Pelaksanaan 7 Kontak ASI terhadap Keberhasilan Menyusui

Hasil penelitian ini menunjukkan bahwa dari 35 orang ibu menyusui bayi $>6$ bulan yang melaksanakan 7 kontak ASI, sebanyak 27 orang $(77,1 \%)$ berhasil menyusui secara ekslusif. Hal ini 
menggambarkan pengetahuan yang didapatkan ibu sejak masa kehamilan hingga persalinan mengenai pentingnya ASI berpengaruh terhadap keberhasilan menyusui secara ekslusif.

Sebanyak 66 orang ibu menyusui bayi $>6$ bulan yang menjadi responden tidak semuanya melakukakan 7 kontak ASI, hanya saja hampir sebagian besar ibu menyusui bayi >6 bulan melakukan 7 kontak ASI (53\%). Sedangkan sebagian besar yang menjadi responden juga berhasil menyusui secara ekslusif $(56,1 \%)$. Sebagian besar responden juga merupakan ibu yang masih berusia 25-35 tahun (72,7\%). Dari wawancara yang dilakukan oleh peneliti didapatkan bahwa sebagian besar responden telah mendapatkan konseling yang cukup mengenai ASI dimulai saat hamil hingga saat persalinan.

Berdasarkan Analisis 7 kontak ASI yang dilakukan pada penelitian ini, dapat dilihat kontak ke 1-2 dengan konseling mengenai memberikan ASI Ekslusif 0-6 bulan selalu diberikan kepada responden $(100 \%)$. Selain itu, kontak ke 3 yang memberikan konseling tentang kontak skin to skin juga dapat dikatakan selalu dilaksanakan (100\%). Namun pada kontak ke 4-5 dengan konseling mengenai memerah ASI dan berikan dengan cangkir hanya $78,8 \%$ dilaksanakan.

Hasil uji statistik dalam penelitian ini menunjukkan terdapat hubungan pelaksanaan 7 kontak ASI terhadap keberhasilan menyusui dimana hasil $\rho$ value uji Chi Square $\rho=0,000$ $(<0,05)$, berarti ada hubungan pelaksanaan 7 kontak ASI terhadap keberhasilan menyusui. Adapun besarnya OR yaitu 7,088 (CI 95\%) yang artinya pelaksanaan 7 Kontak ASI akan meningkatkan 7,088 kali dalam keberhasilan menyusui.

Menurut Ambarwati, et al (2013) mengenai pengaruh konseling laktasi intensif terhadap pemberian air susu ibu (ASI) sampai 3 bulan menunjukkan bahwa konseling laktasi yang intensif meningkatkan jumlah ibu yang memberikan ASI ekslusif. Hasil statistik menunjukkan ada perbedaan praktik pemberian ASI ekslusif antara kelompok kasus dan kontrol $(\rho=0,0001)$. Hasil penelitian ini diperoleh bahwa dari 25 ibu hamil, 12 ibu hamil yang diberi perlakuan hampir sebagian besar ibu hamil memberikan ASI ekslusif yaitu 10 orang $(90,9 \%)$. Sedangkan dari 13 orang ibu hamil sebagai kontrol hanya 1 orang yang memberikan ASI ekslusif (9,1\%). Hal ini menggambarkan adanya perbedaan yang signifikan terhadap perubahan sikap ibu hamil setelah mendapatkan konseling laktasi yang intensif.

Hasil penelitian ini sejalan dengan penelitian yang dilakukan oleh Ramlan, et al (2015) tentang pengaruh konseling gizi dan laktasi intensif dan dukungan suami terhadap pemberian air susu ibu (ASI) ekslusif sampai umur 1 bulan di Kabupaten Muna, Bogor. Hasil uji statistik menunjukkan ada perbedaan praktik pemberian ASI ekslusif antara kelompok perlakuan yaitu kelompok yang diberikan konseling gizi dan laktasi dengan kelompok kontrol $(\rho=0,001)$.

Keberhasilan menyusui dipengaruhi oleh banyak hal, salah satunya adalah pelaksanaan 7 kontak ASI. Menurut Depkes (2007), 7 kontak ASI dalam pelaksanaannya dilakukan melalui 3 tahapan yaitu terutama pada masa kehamilan (periode antenatal care), segera setelah persalinan (perinatal) dan pada masa menyusui selanjutnya (post natal). Hasil penelitian ini diperoleh bahwa dari 66 responden, 35 orang yang melaksanakan 7 kontak ASI sebanyak 27 orang berhasil menyusui ASI ekslusif $(77,1 \%)$.

Penelitian ini sejalan dengan penelitian yang dilakukan oleh Catur E. Sukesty, et al (2016) tentang peran konseling laktasi dengan penerapan media terhadap tingkat keyakinan diri dan keberhasilan menyusui pada ibu post partum. Hasil penelitian menunjukkan bahwa kemampuan menyusui pada kelompok yang diberi koseling laktasi dengan penerapan media lebih tinggi dibanding kelompok yang diberi konseling laktasi dengan asuhan standar dengan $\rho$ value $<0,05$.

Teknik menyusui yang benar adalah cara ibu untuk memberikan ASI kepada bayi dengan pelekatan dan posisi yang baik dan benar. teknik menyusui merupakan salah satu faktor yang berpengaruh dalam pemberian ASI secara ekslusif. pentingnya 7 kontak ASI adalah upaya dalam menjelaskan pentingnya ASI dan cara menyusui dengan baik dan benar (Dennis, 2011)

\section{KESIMPULAN}

Berdasarkan hasil penelitian Analisis Pelaksanaan 7 Kontak ASI terhadap Keberhasilan Menyusui di Wilayah Kerja UPTD Puskesmas Lingkar Barat Kota Bengkulu, dapat disimpulkan bahwa ibu menyusui bayi $>6$ bulan di Wilayah Kerja UPTD Puskesmas Lingkar Barat melaksanakan 7 kontak ASI (53\%) dan berhasil menyusui $(56,1 \%)$. Selain itu, ada hubungan pelaksanaan 7 kontak ASI terhadap keberhasilan menyusui di wilayah kerja UPTD Puskesmas Lingkar Barat dengan nilai $\rho$ value $0,000(<0,05)$. Nilai OR yang didapat yaitu 7,088 yang artinya Pelaksanaan 7 Kontak ASI mempengaruhi 7,088 kali keberhasilan menyusui. 


\section{DAFTAR RUJUKAN}

Ambarwati, Ria dkk. 2013. Pengaruh Konseling Lakstasi Insentitif terhadap Pemberian Air Susu Ibu (ASI) Ekslusif sampai 3 bulan. Jurnal Gizi Indonesia; Vol 2 No. 1: Hal 15-23

Amin, Wirawati dkk. 2014. Pengaruh Faktor Sosial Ibu terhadap Keberhasilan Menyusui pada Dua Bulan Pertama. Jurnal Kedokteran Brawijaya; Vol 28 No. 2: Hal 146-151

BKKBN. 2012. ASI dan Makanan Tambahan. (diakses 10 November 2017), diunduh dari : http://www.sdki.bkkbn.go.id/.

Departemen Kesehatan RI. 2007. Pelatihan Konseling Menyusui. Jakarta: Depkes RI

Departemen of Economic and Social. 2016. SDG's. (diakses 10 November 2017), diunduh dari : http://www.departemenofeconomicandsosial. go.id/

Dinkes Kota Bengkulu. 2016. Profil Kesehatan Kota Bengkulu Tahun 2012. Dinkes Kota Bengkulu: Bengkulu.

Dinkes Provinsi Bengkulu. 2016. Profil Kesehatan Provinsi Bengkulu. Litbangkes dan Informasi Kesehatan Dinas Kesehatan Provinsi Bengkulu: Bengkulu.

Etika, dkk. 2011. Jurnal Praktik Inisiasi Menyusu Dini dan Pemberian ASI Eksklusif Studi Kualitatif pada Dua Puskesmas, Kota Semarang; Vol 45 No. 3: Hal 114-150

Kemenkes RI. 2012. Profil Kesehatan Indonesia Tahun 2012. Kementrian Republik Indonesia: Jakarta.

Notoatmodjo S. 2005. Metodologi Penelitian Kesehatan. PT Rineka Cipta: Jakarta.

Proverawati Atikah., Rahmawati Eni. 2010. Kapita Selekta ASI \& Menyusui. Nuha Medika: Yogyakarta.

Ramlan, dkk. 2012. Pengaruh Konseling Gizi Dan Laktasi Intensif Dan Dukungan Suami Terhadap Pemberian Air Susu Ibu (ASI)
Eksklusif Sampai Umur 1 Bulan. Jurnal Gizi Indonesia. Vol. 3 No. 2: Hal 101-107.

Retna E., Wulandari Diah. 2010. Asuhan Kebidanan Nifas. Nuha Medika: Yogyakarta.

Riyanto, Agus. 2011. Aplikasi Metodologi Penelitian Kesehatan. Nuha Medika: Yogyakata

Roesli Utami. 2009. Mengenal ASI Ekslusif Seri Satu. Trubus Agriwidya: Jakarta.

Sastroasmoro S dan Ismael S. 2010. Dasar-Dasar Metodologi Penelitian Klinis. Sagung Seto: Jakarta.

Setiawan, Yahmin. 2015. Berhasil Menyusui dengan 7 Kontak ASI. (diakses 10 Oktober 2017), diunduh dari http://www.rumah sehat terpadu.or.id/2015/02/25/berhasil-menyusuidengan-7-kontak -ASI.

Silwi, Elizabeth. 2015. Perawatan Kehamilan \& Menyusui Anak Pertama agar Bayi Lahir \& Tumbuh Sehat. Yogyakarta: Pustaka Baru Press

Sukesti, dkk . 2016. Peran Konseling Laktasi Dengan Penerapan Media Terhadap Tingkat Keyakinan Diri Dan Keberhasilan Menyusui Pada Ibu Post Partum. Jurnal IJEMC. Vol 3 No. 2: Hal 48-56

WHO. 2012. Angka Kematian Bayi. (diakses 10 Oktober 2017), diunduh dari : http://www.who.int.org.

Wibowo, Noroyono. 2013. Indonesia Menyusui. (diakses 24 Desember 2017), diunduh dari : http://www.idai.or.id/artikel/klinik/asi/progra m-pranatal-untuk-keberhasilan-menyusui

Yahmin. 2015. Buletin Berhasil Menyusui.(Diakses 10 Oktober 2017), diunduh dari : http://buletinmenyusui.co.id//berhasilmenyusui/2015

Yeyeh., Yulianti L., Liana Meida. 2011. Asuhan Kebidanan III (Nifas). CV. Trans Info Media: Jakarta. 